\title{
PEMANFAATAN CITRA QUICK BIRD DAN SISTEM INFORMASI GEOGRAFIS UNTUK PENYUSUNAN RENCANA PENGEMBANGAN FISIK OBYEK WISATA TELUK PACITAN
}

\author{
Oleh: \\ Nur Khopsun Wibowo \\ Staf Pengajar SMP Negeri 2 Punung Kabupaten Pacitan \\ khopsun@gmail.com
}

\begin{abstract}
Abstrak
Penelitian ini bertujuan mendapatkan data/informasi bentuk lahan, penggunaan lahan, kemampuan lahan, kesesuaian lahan, sebaran fasilitas fisik serta potensi obyek dan daya tarik wisata, untuk menyusun rencana pengembangan fisik obyek wisata Teluk Pacitan. Populasi penelitian berupa unit-unit lahan seluas $2.174,24$ ha dipetakan menjadi 182 grid. Jumlah sampel sebanyak 55 titik ditentukan dengan Purposive Sampling. Sampel tersebut untuk uji ketelitian hasil interpretasi citra Quick Bird. Analisis dengan uji ketelitian hasil interpretasi citra (metode Confusion Matrix Calculation), pengharkatan dan analisis SIG menggunakan software Arc View versi 3.3. Hasil analisis menunjukaan lahan kelas S1 mempunyai luas 523,197 ha, S2 seluas 371,752 ha, S3 seluas 462,102 ha, dan $N$ seluas 817,192 ha. Sebaran fasilitas fisik obyek wisata cenderung mengelompok di wilayah Pantai Teleng Ria dan Pantai Tamperan, sedangkan potensi ODTW tersebar secara merata di setiap wilayah kepesisiran Teluk Pacitan. Rencana pengembangan direkomendasikan dalam 64 blok peruntukan lahan yang dapat dikelompokkan dalam 10 blok pengembangan fisik obyek wisata menurut jenis pengusahaannya.
\end{abstract}

Kata kunci: sistem informasi geografis, rencana pengembangan, obyek wisata, Teluk Pacitan

\begin{abstract}
This research aims to obtain data/information about landform, landuse, land capability, land suitability, distribution of physical facilities as well as the potential of objects and tourist attraction, to plan the physical development of tourism Gulf of Pacitan. The population is in the form of an area of 2174.24 ha units mapped into 182 grid. The samples consist of 55 points determined using purposive sampling. These samples were used to test the accuracy of image interpretation result of Quick Bird. The analysis was performed by testing the accuracy of image interpretation results (confusion matrix calculation method), scoring and FIS analysis using Arc View 3.3. The results show that $\mathrm{S} 1$ class land has an area of 523.197 ha, S2 has 371,752 ha, S3 has 462,102 ha, and N is 817,192 ha. The distribution of physical facilities tend to cluster in the region of Teleng Ria and Tamperan Beach, whereas ODTW potential spreads evenly across every coastal region of the Pacitan Gulf. The development plan was recommended in 64 blocks of land uses which can be grouped into 10 blocks of physical development of tourism based on its type.
\end{abstract}

Keywords: geographic information system, development plan, tourism site, Pacitan Bay 


\section{PENDAHULUAN}

Salah satu upaya untuk meningkatkan nilai manfaat kekayaan alam pesisir adalah melalui pembangunan, pengembangan dan peningkatan sektor kepariwisataan. Mengingat pembangunan pada hakekatnya adalah pemanfaatan sumber daya untuk meningkatkan kesejahteraan, maka pembangunan pariwisata merupakan salah satu usaha untuk mempercepat pertumbuhan ekonomi. Kegiatan pengembangan pariwisata yang semakin meningkat di suatu daerah menjadikan bertambahnya kebutuhan akan sumber daya, terutama ruang karena kegiatan pariwisata membutuhkan lahan.

Pengembangan kepariwisataan di Kabupaten Pacitan memiliki arti yang sangat penting dan strategis, karena sektor pariwisata memberikan sumbangan yang cukup berarti terhadap peningkatan pendapatan asli daerah (PAD). Teluk Pacitan merupakan salah satu obyek wisata unggulan di Kabupaten Pacitan. Pada wilayah kepesisiran Teluk Pacitan terdapat beberapa pantai, diantaranya Pantai Tamperan, Pantai Teleng Ria, Pantai Pancer, dan Pantai Delon, namun dari keempat pantai tersebut yang menjadi ikon wisata adalah Pantai Teleng Ria. Hampir semua kegiatan sektor pariwisata dan pembangunan fisik kawasan Teluk Pacitan terpusat di Pantai Teleng Ria. Hal ini mengindikasikan bahwa pengembangan fisik obyek wisata di kawasan Teluk Pacitan belum merata sehingga diperlukan pemerataan. Pemerataan pengembangan fisik obyek wisata Teluk Pacitan ditujukan untuk menghindari terkonsentrasinya kegiatan pariwisata pada satu area saja.

Pembangunan dan pengembangan suatu obyek dan daya tarik wisata (ODTW) sering kali dihadapkan dengan permasalahan kelestarian lingkungan. Pertimbangan aspek lingkungan fisik yang meliputi karakteristik dan perubahan fisik bentang lahan diperlukan di dalam perencanaan pengembangan pariwisata. Pertimbangan tersebut ditujukan untuk mengetahui daya dukung lahan untuk pengembangan fasilitas fisik pariwisata. Permasalahan yang timbul dalam pengembangan fisik obyek wisata Teluk Pacitan adalah belum diketahuinya kondisi klas kemampuan lahan dan kesesuaian lahan yang mencakup seluruh wilayah kepesisiran, serta data mengenai sebaran fasilitas fisik serta potensi obyek dan daya tarik wisata terutama dalam bentuk data peta.

Sejalan dengan semakin ditingkatkannya penyelenggaraan pariwisata di Kabupaten Pacitan, maka permasalahan yang ada dalam melaksanakan perencanaan pengembangan wilayah pantai adalah penyediaan data serta informasi mengenai potensi wilayah. Data dan informasi yang lengkap, akurat, dan mutakhir tentang potensi sumber daya lahan serta pengolahan data spasial merupakan modal utama dalam menyusun perencanaan dan pengembangan wilayah. Untuk mempercepat diperolehnya data dan informasi tersebut, maka dapat memanfaatkan teknologi penginderaan jauh. Jenis data penginderaan jauh yang dapat dipakai secara intensif dan relatif lengkap adalah citra Quick Bird.

Citra Quick Bird merupakan salah satu data penginderaan jauh yang mudah di akses. Perolehan data citra Quick Bird untuk daerah liputan Teluk Pacitan dapat dilakukan dengan mengakses situs http://earth.google.com. Citra Quick Bird dapat dimanfaatkan secara optimal untuk keperluan penyadapan informasi sumber daya lahan (bentuk lahan dan penggunaan lahan) wilayah kepesisiran Teluk Pacitan. Keunggulan dari citra Quick Bird 
adalah memiliki resolusi spasial paling tinggi dibandingkan dengan citra-citra lain untuk saat ini, yaitu 61 centimeter untuk moda pankromatik dan 2,44 meter untuk multispektralnya, sehingga citra ini mudah diinterpretasi secara visual (http://www.lapanrs.com/pusdata/informasi/publikasi/pdf/bi v1n1 ai 13.pdf).

Peta yang diturunkan dari hasil interpretasi citra Quick Bird dapat dianalisis menggunakan teknologi SIG. Sistem Informasi Geografis (SIG) merupakan salah satu teknologi yang dapat digunakan untuk mempermudah dan mempercepat proses pengolahan data. Teknologi SIG dapat digunakan untuk menganalisa kesesuaian lahan, pembuatan peta-peta tematik, serta analisa perencanaan tata ruang wilayah (Edy Prahasta, 2005: 4-5). Dalam penelitian ini, analisis SIG dimanfaatkan untuk menyusun peta rencana pengembangan fisik obyek wisata Teluk Pacitan.

\section{METODE}

Teknik analisis data yang digunakan dalam penelitian ini antara lain:

1. Uji ketelitian hasil interpretasi citra

Teknik analisis ini menggunakan salah satu jenis metode Short, yakni metode Confusion Matrix Calculation. Uji ketelitian interpretasi citra digunakan untuk mengetahui tingkat keakuratan hasil interpretasi citra Quick Bird.

2. Pengharkatan.

Teknik pengharkatan digunakan untuk menentukan nilai dari tiap variabel jenis tanah, kedalaman efektif tanah, tingkat kelerengan lahan, bahaya erosi, bahaya banjir, kemampuan lahan, dan kesesuaian lahan.

3. Analisis SIG

Fungsi analisis spasialnya menggunakan metode klasifikasi, overlay, dan buffering.

a. Klasifikasi. Fungsi ini digunakan untuk mengklasifikasikan variabel jenis tanah, kedalaman efektif tanah, tingkat kelerengan lahan, bahaya erosi, bahaya banjir, kemampuan lahan, dan kesesuaian lahan.

b. Buffering. Fungsi ini digunakan untuk menghasilkan peta zonasi sempadan pantai dan sempadan sungai.

c. Overlay. Fungsi ini digunakan untuk menghasilkan peta kemampuan lahan, peta kesesuaian lahan, dan peta rencana pengembangan fisik obyek wisata.

Pengolahan dan analisis data dalam penelitian ini meliputi tahap-tahap sebagai berikut:

1. Tahap Persiapan

Pada tahap ini dilakukan studi pustaka (mengumpulkan pustaka yang berkaitan dengan tema penelitian), dan menyiapkan data-data yang dibutuhkan (antara lain citra Quick Bird daerah liputan wilayah kepesisiran Teluk Pacitan, peta-peta tematik pendukung, serta data statistik pendukung). Selanjutnya melakukan orientasi lapangan untuk mengetahui kondisi daerah penelitian.

2. Tahap Interpretasi Citra secara Manual/Visual

Interpretasi citra Quick Bird dilakukan untuk memperoleh informasi bentuk lahan dan penggunaan lahan dengan cara mendeliniasi satuan-satuan bentuk lahan dan 
penggunaan lahan dengan bantuan peta rupa bumi Indonesia lembar 1507-431 skala 1:25.000.

3. Tahap Uji Ketelitian Hasil Interpretasi Citra

Pada tahap ini dilakukan cek lapangan dan uji ketelitian. Perhitungan tingkat ketelitian hasil interpretasi menggunakan metode Short, yakni metode Confusion Matrix Calculation dengan cara membuat matriks dari perhitungan setiap kesalahan pada setiap bentuk lahan dan penggunaan lahan dari hasil interpretasi citra Quick Bird.

4. Tahap Pembuatan Peta Bentuk Lahan dan Penggunaan Lahan (Reinterpretasi Citra)

Setelah dilakukan cek lapangan dan uji ketelitian maka perlu dilakukan interpretasi ulang. Interpretasi ulang ini dilakukan untuk membetulkan hasil interpretasi awal. Semua data hasil cek lapangan dimasukkan ke dalam peta tentatif selanjutnya digunakan untuk membuat peta akhir.

5. Tahap Pemrosesan Data untuk Pembuatan Peta Kelas Kemampuan Lahan dan Kelas Kesesuaian Lahan.

a. Pembuatan Peta Kelas Kemampuan Lahan

Untuk mengetahui kondisi kelas kemampuan lahan dilakukan evaluasi lahan berdasarkan parameter yang telah ditentukan. Parameter diberi harkat berdasarkan atas sifat-sifat yang merupakan potensi dan penghambat dalam penggunaanya secara lestari untuk pengembangan fisik obyek wisata. Parameter yang dianggap memiliki potensi tinggi diberi skor/nilai tinggi, sedangkan parameter yang memiliki penghambat semakin besar maka skornya semakin rendah.

Setelah dilakukan pengharkatan, keenam variable yaitu kemiringan lereng, kepekaan erosi tanah, kedalaman efektif tanah, kelas bahaya banjir, dan jenis tanah kemudian dianalisis (overlay) dan dilakukan penjumlahan semua nilai hasil pengharkatan. Hasil penjumlahan diklasifikasikan dengan berpedoman pada total skor masing-masing. Klasifikasi tersebut dikelompokan ke dalam empat kelas kemampuan lahan.

b. Pembuatan Peta Kelas Kesesuaian Lahan

Dalam menentukan zonasi kelas kesesuaian lahan untuk rencana pengembangan fisik obyek wisata, diperlukan integrasi dari beberapa variabel sebagai berikut, yaitu: data mengenai bentuk lahan; penggunaan lahan; dan data kelas kemampuan lahan. Variabel bentuk lahan, penggunaan lahan dan kelas kemampuan diberi harkat berdasarkan tingkat kesesuaiannya untuk tujuan pengembangan fisik obyek wisata. Parameter yang dianggap memiliki tingkat kesesuaian paling tinggi diberi skor/nilai yang tertinggi.

Setelah dilakukan pengharkatan, ketiga variabel tersebut kemudian dianalisis (overlay) dan dilakukan penjumlahan semua nilai hasil pengharkatan. Hasil penjumlahan diklasifikasikan dengan berpedoman pada total skor masing-masing. Klasifikasi tersebut dikelompokan ke dalam empat kelas kesesuaian lahan. 
6. Tahap Observasi Lapangan untuk Pembuatan Peta Sebaran Fasilitas Fisik dan Potensi Obyek dan Daya Tarik Wisata

Identifikasi mengenai sebaran potensi obyek dan daya tarik wisata beserta fasilitas fisik dilaksanakan dengan dua cara, yaitu dengan mengumpulkan data sekunder dan data primer. Data sekunder diperoleh dari instansi dinas pariwisata daerah. Sedangkan data primer diperoleh dari pengamatan lapangan (observasi).

7. Tahap Pemrosesan Data untuk Pembuatan Peta Rencana Pengembangan Fisik Obyek Wisata

Rencana pengembangan fisik obyek wisata dibuat dengan cara menganalisa data kelas kesesuian lahan dengan memperhatikan kriteria pengelolaan kawasan lindung mengacu pada Keputusan Presiden Republik Indonesia No. 32 tahun 1990 Tentang Pengelolaan Kawasan Lindung (Chafid Fandeli, 2002: 49-50), kemudian disesuaikan dengan kebutuhan fasilitas fisik yang diperlukan untuk pendukung potensi ODTW.

8. Tahap Penyajian

Hasil akhir penelitian ini disajikan dalam bentuk peta yaitu Peta Pengembangan Fisik Obyek Wisata Teluk Pacitan.

\section{HASIL DAN PEMBAHASAN}

Hasil penelitian ini menunjukkan bentuklahan di daerah penelitian bervariasi yang meliputi gisik, beting gisik, dataran aluvial, dataran banjir, delta, gosong sungai, rawa belakang, perbukitan denudasional, perbukitan karst, sungai, dan laut (Tabel 1). Adapun variasi penggunaan lahan berupa hutan, kebun campuran, perkebunan, ladang, sawah, tegalan, tambak, dermaga, lahan kosong, semak/padang rumput, lahan kuburan, permukiman, stadion, sungai, dan laut (Tabel 2).

Tabel 1. Bentuk Lahan di daerah penelitian

\begin{tabular}{|r|l|r|r|}
\hline No. & \multicolumn{1}{|c|}{ Keterangan } & \multicolumn{1}{c|}{ Luas (hektar) } & Persentase (\%) \\
\hline 1. & Gisik & 32,108 & 1,48 \\
\hline 2. & Beting Gisik & 333,033 & 15,32 \\
\hline 3. & Dataran Aluvial & 179,302 & 8,25 \\
\hline 4. & Dataran Banjir & 72,586 & 3,34 \\
\hline 5. & Delta & 7,003 & 0,32 \\
\hline 6. & Gosong Sungai & 3,778 & 0,17 \\
\hline 7. & Rawa Belakang & 7,603 & 0,35 \\
\hline 8. & Perbukitan Denudasional & 249,942 & 11,50 \\
\hline 9. & Perbukitan Karst & 434,167 & 19,97 \\
\hline 10. & Sungai & 37,546 & 1,73 \\
\hline 11. & Laut & 817,174 & 37,58 \\
\hline & Jumlah & 2174,243 & $100 \%$ \\
\hline
\end{tabular}

Sumber: Hasil Reinterpretasi Citra Quick Bird, dan Perhitungan Data Tahun 2007 
Tabel 2. Penggunaan Lahan di daerah penelitian

\begin{tabular}{|c|l|r|r|}
\hline No. & \multicolumn{1}{|c|}{ Keterangan } & Luas (hektar) & Persentase (\%) \\
\hline 1. & Hutan & 455,124 & 20,93 \\
\hline 2. & Kebun Campuran & 112,152 & 5,16 \\
\hline 3. & Perkebunan & 31,543 & 1,45 \\
\hline 4. & Ladang & 38,484 & 1,77 \\
\hline 5. & Sawah & 250,105 & 11,50 \\
\hline 6. & Tegalan & 7,810 & 0,36 \\
\hline 7. & Tambak & 9,071 & 0,42 \\
\hline 8. & Dermaga & 0,335 & 0,02 \\
\hline 9. & Lahan Kosong & 47,057 & 2,16 \\
\hline 10. & Semak/Padang Rumput & 248,926 & 11,45 \\
\hline 11. & Lahan Kuburan & 2,596 & 0,12 \\
\hline 12. & Permukiman & 113,147 & 5,20 \\
\hline 13. & Stadion & 3,507 & 0,16 \\
\hline 14. & Sungai & 37,546 & 1,73 \\
\hline 15. & Laut & 816,840 & 37,57 \\
\hline & & 2174,243 & $100 \%$ \\
\hline
\end{tabular}

Sumber: Hasil Reinterpretasi Citra Quick Bird, dan Perhitungan Data Tahun 2007

Dengan memperhatikan kondisi jenis tanah, kemiringan lereng, kedalaman efektif tanah, bahaya erosi, dan kerawanan banjir, diketahui kemampuan lahan untuk pembangunan fasilitas fisik obyek wisata di daerah penelitian terdiri dari tingkat tinggi, sedang, rendah, dan sangat rendah. Kelas kemampuan tinggi mempunyai potensi sangat baik untuk pembangunan fasilitas fisik obyek wisata, kelas kemampuan sedang mempunyai potensi cukup baik, kelas kemampuan rendah mempunyai potensi jelek, sedangkan kelas sangat rendah mempunyai potensi sangat jelek. Kelas kemampuan sangat rendah paling banyak dijumpai di daerah penelitian yaitu sebesar 37,58\%, kelas kemampuan lahan tinggi sebesar 30,93\%, kelas kemampuan lahan sedang sebesar 30,33\%, adapun kelas kemampuan lahan rendah hanya sebesar 1,15\% (Tabel 3). Distribusi kelas kemampuan lahan di daerah penelitian ditunjukkan oleh Gambar 1.

Tabel 3. Luas per Kelas Kemampuan Lahan

\begin{tabular}{|c|c|l|r|r|}
\hline No. & Kelas & \multicolumn{1}{|c|}{ Kriteria } & Luas (hektar) & \% dari Luas Keseluruhan \\
\hline 1. & I & Tinggi & 672,451 & 30,93 \\
\hline 2. & II & Sedang & 659,508 & 30,33 \\
\hline 3. & III & Rendah & 25,110 & 1,15 \\
\hline 4. & IV & Sangat Rendah & 817,174 & 37,58 \\
\hline & & & 2174,243 & $100 \%$ \\
\hline
\end{tabular}

Adapun mengenai kesesuaian lahan, berdasarkan hasil analisis kesesuaian lahan untuk pembangunan fasilitas fisik obyek wisata terdapat empat kelas kesesuaian lahan yaitu kelas sangat sesuai (S1), sesuai (S2), kurang sesuai (S3), dan tidak sesuai (N). Kelas tidak sesuai paling banyak dijumpai di daerah penelitian (37,59\%), kemudian sangat sesuai (24,06\%), kurang sesuai (21,25\%), dan sesuai (17,10\%). Perhatikan Tabel 4 dan Gambar 2. 

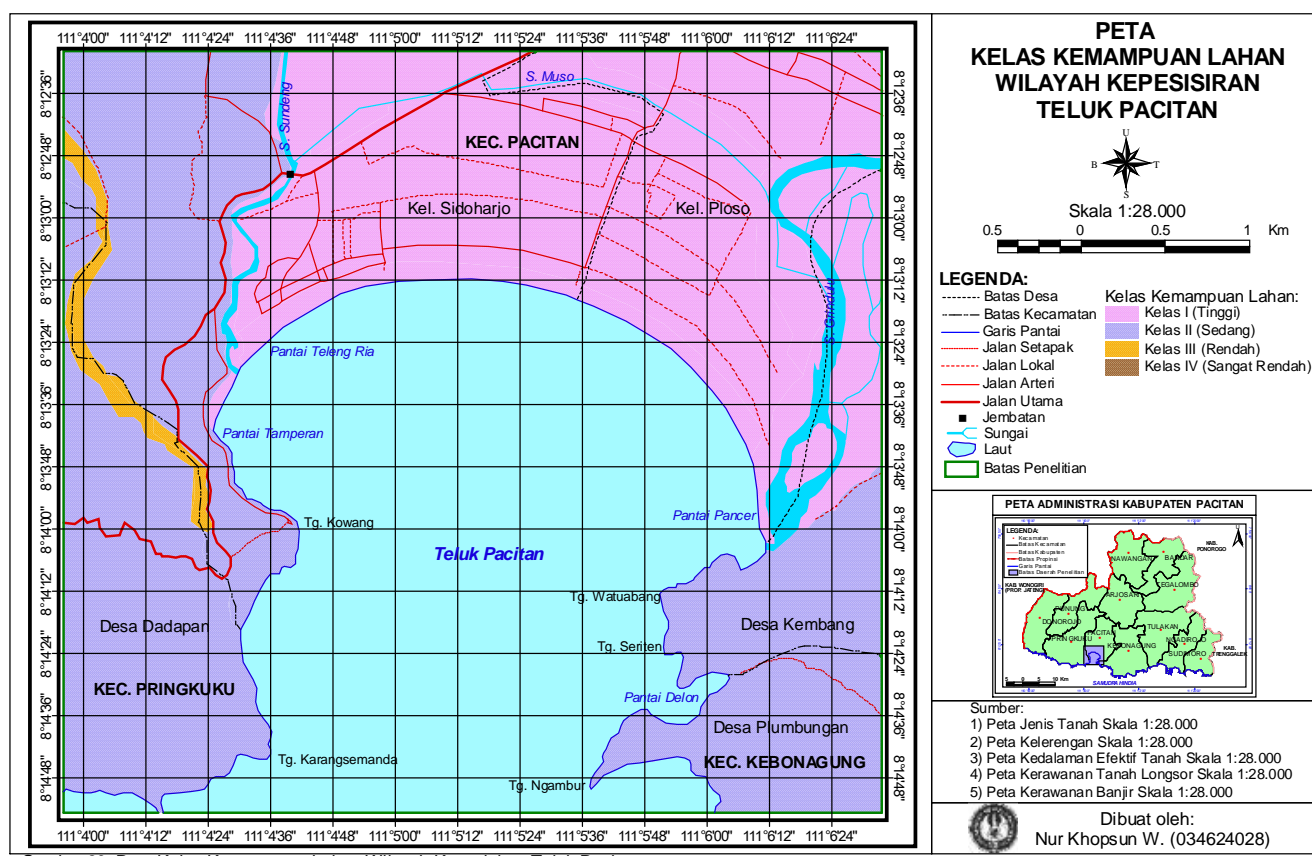

Gambar 1. Peta Kelas Kemampuan Lahan di Wilayah Penelitian

Tabel 4. Luas per Kelas Kesesuaian Lahan

\begin{tabular}{|c|c|l|r|r|}
\hline No. & Kelas & \multicolumn{1}{|c|}{ Kriteria } & Luas (hektar) & \% dari luas keseluruhan \\
\hline 1. & S1 & Sangat Sesuai & 523,197 & 24,06 \\
\hline 2. & S2 & Sesuai & 371,752 & 17,10 \\
\hline 3. & S3 & Kurang Sesuai & 462,102 & 21,25 \\
\hline 4. & N & Tidak Sesuai & 817,192 & 37,59 \\
\hline & & & 2174,243 & $100 \%$ \\
\hline
\end{tabular}

Sumber: Hasil Perhitungan dan Analisis Data Tahun 2007
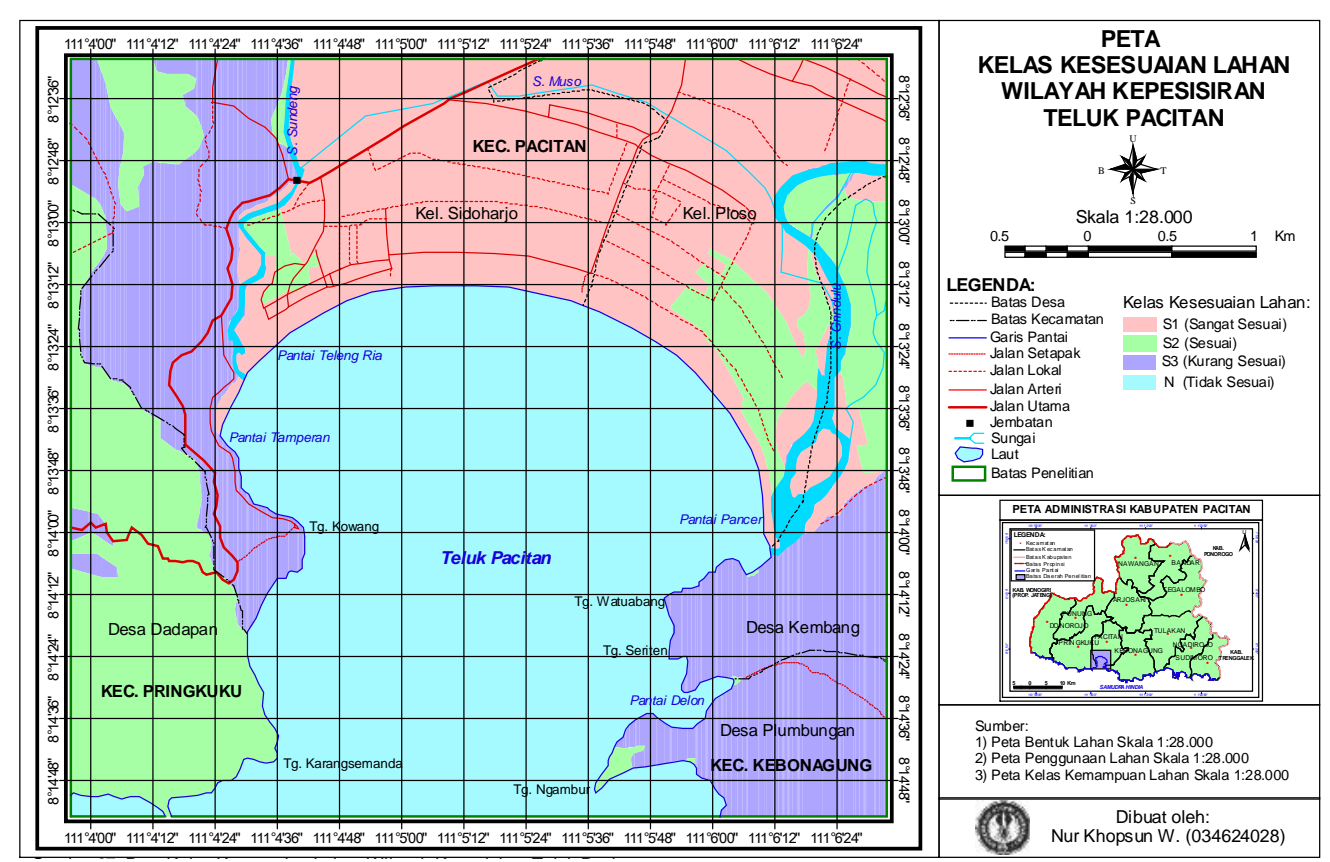

Gambar 2. Peta Kelas Kesesuaian Lahan di Wilayah Penelitian 
Pemanfaatan Ctra Quick Bird dan Sistem Informasi Geografis untuk Penyusunan Rencana Pengembangan Fisik Obyek Wisata Teluk Pacitan

Sebaran fasilitas fisik dan potensi obyek dan daya tarik wisata Teluk Pacitan dapat dideskripsikan pada masing-masing wilayah seperti berikut ini:

1. Wilayah Desa Dadapan

Potensi ODTW yang dimiliki berupa pantai dengan tebing yang terjal (pantai curam) dan atraksi memandang panorama alam Teluk Pacitan serta sun rise di pagi hari.

2. Wilayah Kelurahan Sidoharjo

Termasuk dalam wilayah ini adalah Pantai Tamperan dan Pantai Teleng Ria.

a. Pantai Tamperan

Pada wilayah ini telah terbangun beberapa fasilitas fisik diantaranya adalah jalan penghubung berupa jalan arteri, kafe, kolam renang dengan kondisi rusak dan tidak difungsikan, SPBU (untuk kebutuhan BBM kapal nelayan), TPI Tamperan, dermaga, bangunan loket masuk obyek wisata Tamperan, serta terdapat beberapa warung makan.

Potensi ODTW yang dimiliki berupa pantai curam dengan fenomena rock fall, fenomena escarpment, hutan alami yang terdapat habitat kera, site terbaik untuk memandang panorama alam Teluk Pacitan, serta terdapat peninggalan sejarah berupa benteng bekas pejajahan Belanda.

b. Pantai Teleng Ria

Fasilitas fisik obyek wisata yang telah terbangun diantaranya adalah jalan penghubung berupa jalan arteri, stadion sepak bola, kantor polisi, tourism center, puskesmas, beberapa warung makan dan rumah makan, bangunan loket masuk obyek wisata, area berkemah, bangunan MCK, taman air, taman bermain dan kolam renang anak, mushola, panggung terbuka, kios jajanan ikan, kios cindera mata, TPI Teleng Ria, lapangan parker, home stay, bungalow, lapangan udara, sirkuit motor cross, menara SAR, serta gasebo.

Potensi ODTW yang dimiliki berupa pantai landai dengan gisik pasir yang luas dan pemandangan panorama alam pantai, memiliki empasan gelombang tipe plunging untuk olah raga surfing, zona perairan laut bisa dimanfaatkan untuk boating, ketika empasan gelombang tidak terlalu besar maka bisa dimanfaatkan untuk berenang, terdapat estuaria/muara Sungai Sundeng, serta terdapat areal tambak yang bisa difungsikan sebagai area pemancingan.

3. Wilayah Kelurahan Ploso

Fasilitas fisik obyek wisata yang terbangun adalah loket masuk obyek wisata. Potensi ODTW berupa pantai landai dengan gisik pasir yang luas, empasan gelombang dengan tipe plunging untuk surfing, hutan mini untuk area berkemah, serta terdapat estuaria/muara Sungai Grindulu dan delta Sungai Grindulu.

4. Wilayah Desa Kembang

Fasilitas fisik obyek wisata yang terbangun yaitu tambak udang dan TPI Kembang. Potensi ODTW berupa pantai dengan tebing terjal dan suasana hutan yang masih alami.

Pada wilayah ini terdapat Pantai Delon. Bentuknya berupa teluk yang sempit, empasan gelombang tidak terlalu besar dan perairannya relatif tenang. Pantai dengan karakter demikian dapat dimanfaatkan untuk olah raga berkano dan berenang. 


\section{Wilayah Desa Plumbungan}

Fasilitas fisik yang terbangun hanyalah mercusuar. Terdapat Tanjung Ngambur dan juga fenomena batu piramid.

Rencana pengembangan obyek wisata teluk pacitan direkomendasikan 64 blok peruntukan lahan untuk rencana pengembangan fisik obyek wisata. Berdasarkan rekomendasi blok peruntukan lahan, maka pengelompokan blok pengembangan fisik obyek wisata Teluk Pacitan menurut jenis pengusahaannya adalah sebagai berikut:

1. Blok Pengembangan Prasarana Pelayanan Umum

Fasilitas fisik yang didirikan meliputi :

a. Kantor polisi (Polsekta Pacitan)

Blok ini berada pada lahan dengan kelas kesesuaian S1. Didirikan di dekat pertigaan jalan utama menuju obyek Pantai Teleng Ria.

b. Tourism Center (Kantor Disbudpar Kab. Pacitan)

Blok ini berada pada lahan dengan kelas kesesuaian S1. Didirikan di dekat pertigaan jalan utama menuju obyek Pantai Teleng Ria.

c. Puskesmas dan apotik

Blok ini berada pada lahan dengan kelas kesesuaian S1. Didirikan di dekat jalan arteri menuju obyek wisata Pantai Teleng Ria.

d. SPBU

Terletak pada kelas kesesuaian lahan S1 di Dermaga Tamperan.

2. Blok Pengembangan Sarana Akomodasi

Fasilitas fisik yang didirikan meliputi:

a. Bungalow

Blok ini berada pada lahan dengan kelas kesesuaian S1.

b. Cottage

Blok ini berada pada lahan dengan kelas kesesuaian S1 dan S3.

c. Home stay

Blok ini berada pada lahan dengan kelas kesesuaian S1 dan S2.

d. Hotel Resort 1 dan 2

Blok ini berada pada lahan dengan kelas kesesuaian S1.

e. Hotel dan Restoran

Blok ini berada pada lahan dengan kelas kesesuaian S1.

f. Vila

Berada pada lahan dengan kelas kesesuaian S2. Bangunan dengan pola berderet memanjang dari sebelah selatan jalan utama sampai mendekati Tanjung Karangsemanda.

3. Blok Pengembangan Sarana Makanan dan Minuman

Fasilitas fisik yang didirikan meliputi:

a. Rumah makan

Berada pada lahan dengan kelas kesesuaian S1. Didirikan di sebelah timur, luar zona sempadan sungai Sungai Sundeng. 
Pemanfaatan Ctra Quick Bird dan Sistem Informasi Geografis untuk Penyusunan Rencana Pengembangan Fisik Obyek Wisata Teluk Pacitan

\section{b. Warung makan}

Berada pada lahan dengan kelas kesesuaian S1 pada area obyek wisata Pantai Teleng Ria.

c. Kafe

Blok ini berada pada lahan dengan kelas kesesuaian S1dan S2.

4. Blok Pengembangan Prasarana Perbelanjaan dan Jasa Persewaan Peralatan Penunjang Kegiatan Wisata

Fasilitas fisik yang didirikan meliputi:

a. Pertokoan

Blok ini berada pada lahan dengan kelas kesesuaian S1 dan S2. Didirikan di sebelah jalan arteri menuju obyek Pantai Teleng Ria.

b. Kios PKL jajanan ikan

Pada lahan dengan kelas kesesuaian S1 dekat TPI Teleng Ria.

c. Kios PKL jajanan kering

Pada lahan dengan kelas kesesuaian lahan S1 di sebelah timur kios PKL jajanan ikan.

d. Kios PKL cinderamata

Blok ini berada pada lahan dengan kelas kesesuaian S1 didirikan di sebelah timur kios PKL jajanan kering.

e. Kios persewaan peralatan penunjang kegiatan wisata

Pada lahan dengan kelas kesesuaian S1 sekitar Pantai Teleng Ria.

5. Blok Pengembangan Sarana Olah Raga

Fasilitas fisik yang didirikan meliputi:

a. Lapangan sepak bola pantai

Blok ada lahan dengan kelas kesesuaian S1. Didirikan di sebelah selatan/di depan bangunan hotel resort.

b. Lapangan bola voli pantai

Blok ini berada pada lahan dengan kelas kesesuaian S1. Didirikan di sebelah barat lapangan sepak bola pantai.

c. Sirkuit motor cross

Blok ini berada pada lahan dengan kelas kesesuaian S1. Didirikan di sebelah barat lapangan bola voli pantai.

d. Stadion

Blok ini berada pada lahan dengan kelas kesesuaian S1. Didirikan di sebelah utara kantor polisi dan tourism center.

6. Blok Pengembangan Pelestarian Alam

Blok pengembangan pelestarian alam meliputi:

a. Hutan lindung

Blok ini sebagian besar berada pada lahan dengan kelas kesesuaian S3.

Diperuntukkan guna pengaturan tata air, pencegahan bencana banjir dan erosi serta pemeliharaan kesuburan tanah 
b. Hutan produksi

Tanaman yang diusahakan biasanya adalah tanaman keras jenis jati, karena struktur tanahnya berupa tanah kapur. Blok ini berada pada lahan dengan kelas kesesuaian S2 dan S3.

c. Hutan mini

Kegiatan yang bisa dilakukan antara lain berkemah dan kegiatan out bond. Berada pada lahan dengan kelas kesesuaian S1 dan S2.

d. Zona sempadan pantai dan sempadan sungai

Di tetapkan selebar 100 meter dari titik pasang tertinggi pada daerah yang berpantai landai dan selebar 50 meter di kanan kiri aliran Sungai Grindulu dan Sungai Sundeng.

7. Blok Pengembangan Atraksi Wisata

Blok atraksi wisata yang dikembangankan meliputi:

a. Area berkemah

Blok ini dapat didirikan ditengah hutan mini dan di kawasan hutan lindung. Berada pada kelas kesesuaian S1 dan S2.

b. Taman air

Didirikan pada kelas kesesuaian S1 dan S2 dengan memanfaatkan aliran Sungai Sundeng pada kawasan obyek Pantai Teleng Ria.

c. Taman bermain anak

Blok ini didirikan pada kelas kesesuaian lahan S1 dan S2 pada kawasan obyek wisata Pantai Teleng Ria.

d. Taman wisata

Didirikan pada kelas kesesuaian S1 kawasan Pantai Teleng Ria.

e. Taman stadion

Blok ini didirikan pada kelas kesesuaian lahan S1di sekitar stadion.

f. Area pemancingan

Didirikan pada kelas kesesuaian S2 kawasan Pantai Teleng Ria.

g. TPI Tamperan

Terletak di kawasan Pantai Tamperan dengan kelas kesesuaian S1.

h. TPI Teleng Ria

Terletak di kawasan Pantai Teleng Ria dengan kelas kesesuaian S1.

8. Blok Pengembangan Sarana Pelengkap Kepariwisataan

Blok pengembangan ini meliputi:

a. Base camp trecking

Didirikan sebagai pos persiapan kegiatan wisata jungle trecking hutan lindung Kembang-Plumbungan. Pada kelas kesesuaian S2.

b. Gardu pandang

Terletak di Tanjung Karangsemanda, Tanjung Kowang, Tanjung Watuabang, dan Tanjung Ngambur. Pada kelas kesesuaian S3.

c. MCK

Tersebar pada obyek wisata yang padat kunjungan wisatawannya. 
Pemanfaatan Ctra Quick Bird dan Sistem Informasi Geografis untuk Penyusunan Rencana Pengembangan Fisik Obyek Wisata Teluk Pacitan

d. Mushola

Berada pada kelas kesesuaian S1 di kawasan Pantai Teleng Ria.

e. Panggung terbuka

Berada pada kelas kesesuaian S1 di kawasan Pantai Teleng Ria.

f. Loket masuk

Tersebar di tiga tempat, yaitu pintu masuk Pantai Tamperan, Pantai Teleng Ria, dan Pantai Pancer. Pada kelas kesesuaian S1 dan S3.

g. Menara pengawas pantai

Terdapat di Pantai Teleng Ria, dan Pantai Pancer. Didirikan pada zona sempadan pantai dengan kelas kesesuaian lahan S1.

h. Gasebo

Pembangunan berderet sepanjang pesisir Pantai Teleng Ria hingga Pancer. Pada zona sempadan pantai dengan kelas kesesuaian S1.

i. Shower

Pembangunan fasilitas shower berada Pantai Teleng Ria dan Pantai Pancer. Pada zona sempadan pantai dengan kelas kesesuaian S1.

9. Blok Pengembangan Prasarana Transportasi

Rincian pengembangannya adalah sebagai berikut:

a. Jalan utama

Terletak pada kelas kesesuian lahan S1, S2, dan S3. Jalan utama dibangun sepanjang $5,862 \mathrm{~km}$

b. Jalan arteri

Terletak pada kelas kesesuian lahan S1, S2, dan S3. Jalan arteri dibangun sepanjang $28,453 \mathrm{~km}$.

c. Jalan lokal

Terletak pada kelas kesesuian lahan S2, dan S3. Jalan lokal dibangun sepanjang 7,486 $\mathrm{km}$.

d. Jalan setapak

Terletak pada kelas kesesuian lahan S3. Jalan setapak dibangun sepanjang 4,685 km. Jalur terpanjang jalan setapak berada di kawasan hutan lindung Desa Kembang Plumbungan.

e. Jembatan

Berfungsi sebagai penghubung jalan utama yang melintas di atas Sungai Sundeng. Terletak pada kelas kesesuian lahan S1, dan S3.

f. Jembatan gantung

Berfungsi sebagai penghubung antara wilayah yang berada di sebelah barat dengan wilayah yang berada di sebelah timur Sungai Grindulu. Terletak pada kelas kesesuian S1 dan S3.

g. Pedestrian

Terletak di pinggir kanan dan kiri jalan arteri menuju obyek wisata Pantai Teleng Ria, serta pada sisi selatan jalan arteri dibelakang zona sempadan pantai memanjang 
mulai dari Pantai Teleng Ria hingga Pantai Pancer. Berada pada kelas kesesuaian S1 dan S2.

h. Area parkir

Meliputi area parkir stadion dan area parkir disekitar obyek wisata. Terletak pada kelas kesesuian lahan S1.

i. Dermaga

Terletak pada tubuh perairan laut wilayah Pantai Tamperan.

j. Pelabuhan udara

Fasilitas ini merupakan bangunan milik TNI AU. Terletak pada pada lahan dengan kelas kesesuaian $\mathrm{S} 1$.

10. Blok Pengembangan Prasarana dan Sarana Lainnya

Rincian blok pengembangan adalah sebagai berikut:

1) Tambak

Berada di dekat muara Sungai Grindulu. Berdiri diatas lahan dengan kelas kesesuaian S2.

2) Lahan pertanian

Berada pada lahan dengan kelas kesesuaian S1 dan S2. Terletak di wilayah Kelurahan Sidoharjo, Ploso, dan Desa Kembang.

3) Perkebunan

Berada pada lahan dengan kelas kesesuaian S1 dan S2. Secara administratif terletak di wilayah Kelurahan Sidoharjo.

4) Mercusuar

Fasilitas ini didirikan di Tanjung Ngambur. Berada pada lahan dengan kelas kesesuaian S2.

5) Permukiman

Berada pada lahan dengan kelas kesesuaian S1, S2 dan S3. Terletak di wilayah Kelurahan Sidoharjo, Ploso, dan Desa Dadapan.

6) Gudang Bulog

Pada lahan dengan kelas kesesuaian S1 (Kelurahan Sidoharjo).

7) Lahan kuburan

Pada lahan dengan kelas kesesuaian S1 (Kelurahan Sidoharjo).

Gambaran mengenai blok rekomendasi pengembangan dapat dilihat pada peta rencana pengembangan fisik obyek wisata Teluk Pacitan. 


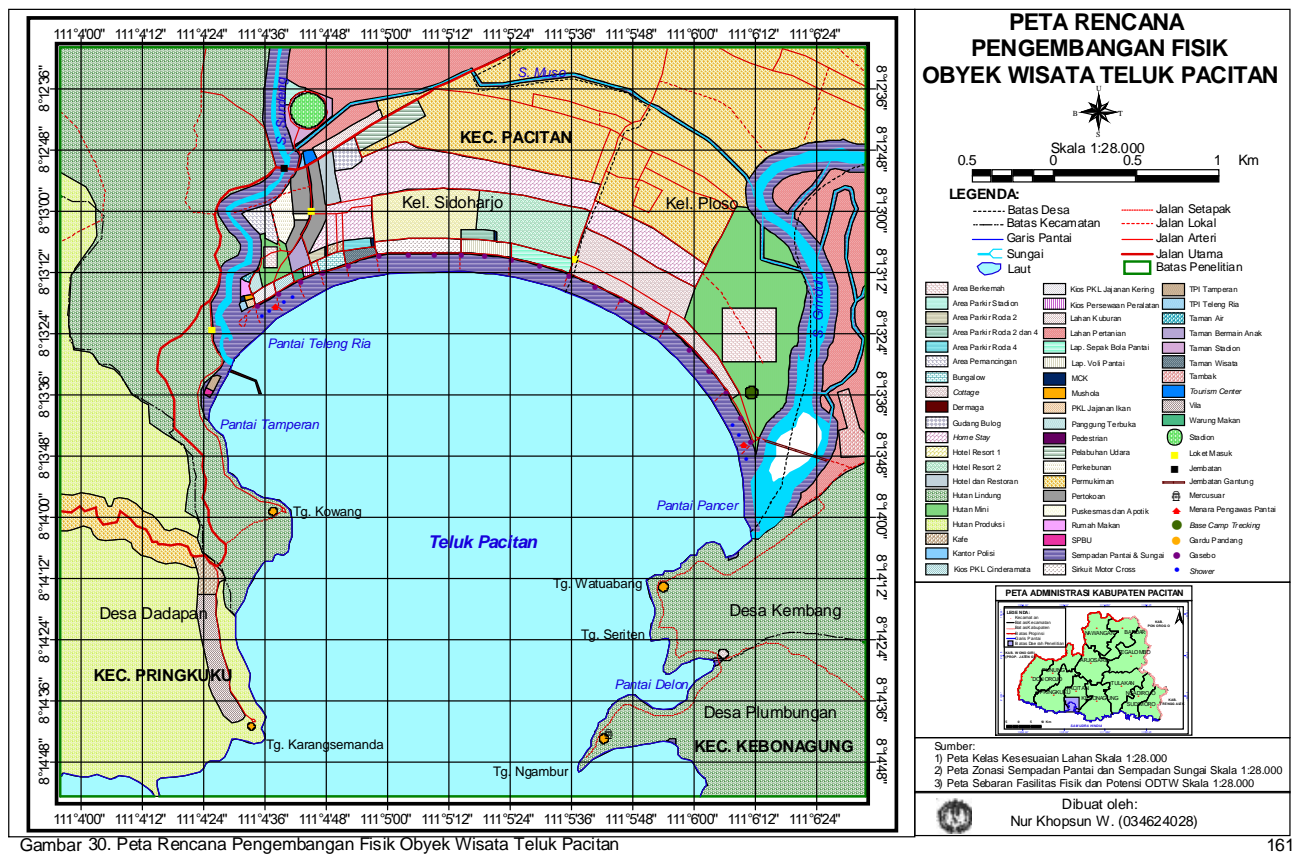

Gambar 3: "Peta Rencana Pengembangan Fisik Obyek Wisata Teluk Pacitan"

\section{SIMPULAN}

Berdasarkan hasil penelitian dan pembahasan dapat ditarik beberapa kesimpulan sebagai berikut:

a. Pemanfaatan citra Quick Bird daerah liputan wilayah kepesisiran Teluk Pacitan pengolahan data tahun 2007 untuk penyadapan data bentuk lahan menunjukkan bahwa pada wilayah penelitian terdapat 11 jenis bentuk lahan dan 15 jenis penggunaan lahan.

b. Pada wilayah penelitian, persentase kelas kemampuan lahan adalah: kelas I 30,93\%, kelas II 30,33\%, kelas III 1,15\%, dan kelas IV 37,58\%. Sedangkan persentase kelas kesesuaian lahan adalah: kelas S1 24,06\%, kelas S2 17,10\%, kelas S3 21,25\%, dan kelas N $37,59 \%$

c. Sebaran fasilitas fisik obyek wisata pada wilayah kepesisiran Teluk Pacitan cenderung mengelompok pada wilayah bagian barat, yaitu di sekitar Pantai Teleng Ria dan Pantai Tamperan. Sedangkan potensi obyek dan daya tarik wisata tersebar secara merata di setiap wilayah kepesisiran Teluk Pacitan.

2. Rekomendasi rencana pengembangan fisik obyek wisata Teluk Pacitan dibagi menjadi 64 blok peruntukan lahan. Blok peruntukan lahan ini dapat dikelompokkan kedalam 10 blok pengembangan fisik obyek wisata menurut jenis pengusahaannya. 10 blok pengembangan fisik obyek wisata tersebut ialah: blok pengembangan prasarana 
pelayanan umum, blok pengembangan sarana akomodasi, blok pengembangan sarana makanan dan minuman, blok pengembangan sarana perbelanjaan dan jasa persewaan peralatan penunjang kegiatan wisata, blok pengembangan sarana olah raga, blok pengembangan pelesatarian alam, blok pengembangan atraksi wisata, blok pengembangan sarana pelengkap kepariwisataan, blok pengembangan prasarana transportasi, blok pengembangan prasarana dan sarana lainnya.

\section{UCAPAN TERIMA KASIH}

Dalam kesempatan ini penulis mengucapkan terima kasih kepada berbagai pihak yang telah membantu dalam proses penelitian ini. Penulis juga mengucapkan terima kasih kepada redaksi Jurnal Geo Media sehingga artikel ini dapat dimuat pada Volume 14 Nomor 2, November 2016.

\section{DAFTAR PUSTAKA}

Chafid Fandeli. 2002. Perencanaan Kepariwisataan Alam. Yogyakarta: Fakultas Kehutanan UGM.

Edy Prahasta. 2005. Konsep-konsep Dasar Sistem Informasi Geografis. Bandung: Penerbit Informatika.

Projo Danoedoro. Satelit Mata-mata untuk Lingkungan. (http://www.lapanrs.com/pusdata/informasi/publikasi/pdf/bi v1n1 ai 13.pdf), diakses tanggal 20 Juli 2007.

Sugeng S. Suryono, dkk. 2002. Buku Panduan Ekskursi Geologi Regional 2002 Jawa Tengah - Jawa Timur. Jurusan Teknik Geologi FT UGM. Yogyakarta.

Tim Puspics UGM dan Bakosurtanal. 1988. Identifikasi Bentuk Lahan dan Interpretasi Citra untuk Geomorfologi. Yogyakarta: Badan Penerbit dan Percetakan Fakultas Geografi UGM. 